\title{
Effect of Aflatoxin Contaminated Feed on Growth and Survival of Fish Labeo Rohita (Hamilton)
}

\author{
DURRE SHAHWAR RUBY ${ }^{1}$, AHMAD MASOOD ${ }^{2}$ and AMJAD FATMI ${ }^{3}$ \\ 'Department of Zoology, B.S College, Danapur, Patna, Bihar, India. \\ ${ }^{2}$ Department of Botany, H.D Jain College, Ara, Bihar, India. \\ ${ }^{3}$ Department of Zoology, Govt. P.G College, Dholpur, Rajasthan, India.
}

http://dx.doi.org/10.12944/CWE.8.3.19

(Received: August 03, 2013; Accepted: September 17, 2013)

\begin{abstract}
Effect of aflatoxin contaminated feed on growth, survival and behaviour of the fish Labeo rohita was evaluated. There was a significant decrease in the growth rate and survival percentage of the fish with the increase in the amount of aflatoxin contaminated feed in the food of the fish.
\end{abstract}

Key words : Aflatoxin, Labeo Rohita, Growth rate.

\section{INTRODUCTION}

Aflatoxin is the metabolic by product of mols Aspergillus flavus and Aspergillus parasiticus.It is a toxic compound and the cause of high mortality in livestock, poultry and in some cases of human beings (Reed and Kasali.,1987, Montessano et al.1995). Toxicogenic A. Flavus . produces Aflatoxin B1 and B2 whereas A. Parasiticus produces Aflatoxin G1 and G2.Aflatoxin B1 is classified as group I carcinogen by international agency for research on cancer. Effect of aflatoxin on fishes and other animals have been reported by many workers. Nunez et al. (1991) reported hepatocellular adenoma and hepatocellular carcinoma in Rainbow trout when exposed to aflaroxin B1.Caguan et al. (2004) reported loss of appetite, low survival percent and decreased mean total biomass in tilapia when fed with aflatoxin contaminated feed. Faisal et al . (2008) reported spermatotoxic effect of aflatoxin in male wister rat.

Labeo rohita a common Indian carp is widely distributed in Indian rivers and ponds. It is very important as a human food for its high quality flesh. In the present investigation effect of aflatoxin on growth rate, survival percentage and behavioural changes of Labeo rohita has been evaluated in order to explore the effect of toxin in the fish.

\section{MATERIALS AND METHODS}

The fish Labeo rohita was collected from river sone near Ara. 72 fishes measuring about10 $20 \mathrm{~cm}$ and weighing about $30-50 \mathrm{gm}$ were selected and kept in twelve aquaria measuring $3^{1} \times 2^{1} \times 1^{1}$. Six fishes were kept in each aquarium. Three aquaria containing six fishes each were kept as control and nine aquaria containing six fishes each were kept as experimental set.

Four feeds were employed as follows:

1. Feed I or good feed contained $0 \%$ moldy feed or unmixed feed. Feed I were given to control.

2. Feed II contained $10 \%$ moldy feed and $90 \%$ good feed. Feed II were given to first set of experimental fishes comprising aquaria $2 \mathrm{~A}$, $2 \mathrm{~B}$ and $2 \mathrm{C}$.

3. Feed III contained $50 \%$ good feed and $50 \%$ moldy feed. Feed III were given to second set of experimental fishes comprising three aquaria $3 \mathrm{~A}, 3 \mathrm{~B}$ and $3 \mathrm{C}$. 
4. Feed IV contained $100 \%$ moldy feed. Feed IV was given to fourth set of fishes comprising three aquaria $4 \mathrm{~A}, 4 \mathrm{~B}$ and $4 \mathrm{C}$.

Moldy feed were prepared in laboratory. The commercial fish feed was first sprinkled with small amount of tap water to make the feed moist and then infected with cultured Aspergillus flavus by mixing $10 \mathrm{ml}$ of cultured Aspergillus flavus. The inoculation was made in a transfer chamber to avoid contamination. The mixed feed was then covered with a plastic sack. The infected feed was kept in a condition which is favourable for the growth of mold. Required amount of moldy feed and good feed were weighed carefully for each treatment and then mixed thoroughly. The fish were fed a day after and and daily there after two times a day at $8.00 \mathrm{am}$ and at $6.00 \mathrm{pm}$ at a feeding rate of $4 \%$ of the body weight .

Data gathered were initial and final individual length and weight, average body length gain and average body weight gain, specific growth rate, survival percentage and behavioural changes.

\section{RESULTS AND DISCUSSION}

\section{Body Weight and Body Length}

Body weight gain in aflatoxin treated fishes showed significant decrease $(p>0.05)$ as compared to control or fishes given feed I or mold free feed. The average body weight gain in the fishes treated with feed IV was $60.3 \mathrm{gm}$ as compared to $79.5 \mathrm{gm}$ in fishes fed with feed I. The growth rate,Specific

Table 1: Mean along with their standard errors (S.E.) and coefficient of variation of body length in different groups of fishes showing the effect of aflatoxin contaminated feed.

\begin{tabular}{lcccccc}
\hline Feed & I & II & III & IV & Total mean \pm S.E. & C.V. \% \\
\hline Body Length (Initial) & 11.1 & 10.9 & 11.0 & 11.8 & 11.2 & 3.1 \\
& \pm .05 & \pm 0.25 & \pm 0.29 & \pm 0.19 & \pm 0.17 & \\
Body Length (final) & 20.9 & 18.5 & 16.8 & 16.2 & 13.3 & 13.6 \\
& \pm .15 & \pm 0.22 & \pm 0.16 & \pm 0.24 & \pm 0.91 & \\
Average Body length gain & 9.8 & 7.6 & 5.8 & 4.4 & & \\
\% Body Length Gain & $88.2 \%$ & $69.7 \%$ & $52.7 \%$ & $37.2 \%$ & & \\
\hline
\end{tabular}

Table 2: Mean along with their standard errors (S.E.) and coefficient of variation of Body weight in different groups of fishes showing the effect of aflatoxin contaminated feed.

\begin{tabular}{lcccccc}
\hline Feed & I & II & III & IV & Total mean \pm S.E. & C.V. \% \\
\hline Body weight (Initial) & 41.2 & 40.4 & 42.3 & 41.6 & 41.3 & 1.67 \\
& \pm .66 & \pm 1.53 & \pm 1.67 & \pm 1.58 & \pm 0.43 & \\
Body weight (Final) & 120.7 & 113.2 & 108.5 & 101.9 & 111.07 & 6.33 \\
& \pm .63 & \pm 0.60 & \pm 1.02 & \pm 0.93 & \pm 0.00 & \\
Average Body weight gain & 79.5 & 72.8 & 66.2 & 60.3 & & \\
\% Body weight Gain & 192.9 & 180.1 & 156.5 & 144.9 & & \\
Growth rate & 0.88 & 0.80 & 0.73 & 0.67 & & \\
Specific growth rate & $88 \%$ & $80 \%$ & $73 \%$ & $67 \%$ & & \\
\hline
\end{tabular}

Table 3: Survival Percentage and coefficient of variation percentage of Survival in different groups of fishes showing effect of aflatoxin contaminated feed.

\begin{tabular}{lcccccc}
\hline Feed & I & II & III & IV & Total mean \pm S.E. & C.V.\% \\
\hline Survival $\%$ & 100 & 83 & 61 & 44 & $72 \pm 10.63$ & 29.5 \\
\hline
\end{tabular}


growth rate and percent body weight gain was also high in fishes fed with feed I and decreased gradually with increase in percentage of moldy feed in the food reaching its minimum in those fishes which were given feed IV or 100 percent moldy feed(Table II). The average body length gain and percent body length gain was also significantly lower( $p>0.05)$ in fishes fed with feed II, II and III as compared to fishes given feed I or mold free feed(Table I). These results agree with the findings of Jantrarotai and lovel (1990) in Oreochromis aureaus, Roges et al. (2002) in Oreochromis nilotius, Nguyen et al. (2002) in Juvenile NileTilapia and Zaki et al. (2012) in Clarius lazera. Joner et al. (2000) reported that aflatoxin reacts negatively with different cell protein which leads to inhibition of carbohydrate and lipid metabolism and protein synthesis. So the decrease in growth rate in experimental fish may be due to disturbance in metabolic process of carbohydrates, lipids and proteins by aflatoxin. Cheeke and shull (1985) reported that aflatoxin causes loss of appetite. Thus the decrease in average weight gain and body length increase may also be due to loss of appetite. Also it might be due to utilization of glutathione enzymes for detoxification process under the condition of Stress Devegowda et al. (1998). Glutathione enzymes are partly consist of methionine and cystein and hence this process of detoxification decreases availability of methionine resulting in poor growth in the fish.

\section{Swimming, Feeding and Opercular Movement}

The fishes fed with aflatoxin containing feed depicted less swimming, mostly off feed and greater opercular movement as compared to those fish group which were given aflatoxin free diet. Thus the present finding are in agreement with those of Boshy et al. (2008) and Caguan et al. (2004)in Nile tilapia. Aflatoxin causes loss of appetite thus creates weakness resulting in less agility and off food behavior in fishes as a result of aflatoxin. Aflatoxin induces stress and thereby increases oxygen demand resulting in greater opercular movement in fishes received aflatoxin containing food.

\section{Survival Percentage}

Survival percentage decreased with increase in aflatoxin containing feed. The fishes which were given aflatoxin free diet or feed I showed hundred percent survival whereas minimum survival ie forty four percent was found in those fishes which were fed with feed IV(Table III). Thus the present findigs are in agreement with those of Caguan et al. (2004). The decreased survival percentage was probably due to impaired liver function, loss of appetite and decreased immunity as a result of aflatoxin.

\section{REFRENCES}

1. Jantrorotai. W; Lovell,R.T. Subchronic toxicity of diatary aflatoxin $\mathrm{B}_{1}$ to channel cat fish. Journal of Aquatic animal health 2: 248-254. In chickens. Mycopathologia, 104: 33-36 (1990).

2. Joner A. Mycotoxine (http : // www. Ansci cornell . edu / courses / as625 / 1999 term / toner / aflatoxin. Html) (2000).

3. Cheeke. P.K ; Shull. L.R. Natural Toxicant in feeds and poisonous plants. Abi. Publishing company. ING. West Port. Connecticut, (1985).

4. Nguyen, A.T; Grizzle,J.M; Lovoll,R.T; Manning,B.B; Rottinghaus, G.E. Growth and hepatic lesions of Nile tilapia fed diet containing aflatoxin $\mathrm{B}_{1}$. Aquaculture, 217 : 311-319 (2002).

5. Roges, J.B; yanong, R.P.E. Molds in fish and aflatoxin (http \edie. 1 fas. Vtrl.edu. \FA095)
(2002).

6. Zaki, M. S. Effect of aflatoxin on endocrine status in cat fish (Clarius lazera).Life sci. $j$. 9(1): 419-422 (2012).

7. Caguan, A .G; Tayaban,R.H ; J.R. Somga; Bartolome,R.M. Effect of Aflatoxin Contaminated feed in Nile tilapia (Oreochromis niloticus L.). In Proceeding of the $6^{\text {th }}$ International symposium on tilapia in aquaculture (R.B. Remedios, G.C. Imir and K. Fitzsimons. eds.). :172-178 (2004).

8. Boshy EL, M.E; Ashram, A.M.M.EL; Nadia A. Abdel-Ghany. Effect of diatary beta-A, 3, glucagon on immunomodulation on diseased oreochromis niloticus experimently infected with Aflatoxin B1. $8^{\text {th }}$ International symporium on tilapia in aquaculture, (2008).

9. Montesano,R; Hainut,P; Wild,C.P. 
Hepatocellular carcinoma : From gene to public health review.J.Nat. Cancer Inst.89:1844-1851, (1997).

10. Devegoda ,G; Raju,M.L.N.V; Afzali, N; Swamy, H.V.L.N. Mycotoxins picture world wide: Novel solution for their counteraction. In T.P. Lyons and K.A. Jacques(Eds) Biotechnology in the feed Industry,pp241255.Proc.ofAlltech's 14, the Annual Symposium. Nottingham. U.K, (1998).

11. Nunez.J.D.H; Duimishra, J. R. Ultra structure of hepato cellular neoplasms in aflatoxin $B_{1}$ $\left(\mathrm{AFB}_{1}\right.$ ) initiated rainbow trout (Oncorhychus mykiss). Toxicol Pathol. 19 (i) 11-21, (1991).
12. Reed,J.D;Casali,O.B. Hazards to livestock consuming aflatoxin contaminated meal in Africa. In: ICRISAT proceeding of international workshop on aflatoxin contamination in ground nut. 6-9 Oct.1987, (1987).

13. Faisal. K ; perisamy , V. S. ; Sahabuddin ,S ; Radha , A ; Anandhi ,R; Akbarsha, M. A. Spermatotoxic effect of aflatoxin $B_{1}$ in rat : extrusion of outer dense fibers and associated axonemal microtubule doublets of sperm flagellum . J. Soci. Repro. Fert. 135 : 303 - 310, (2008). 